\title{
Teachers' Questioning Strategies to Promote Students' Critical Thinking in EFL Classroom: Perceptions And Practices
}

\author{
Angella Novitaningrum ${ }^{1, a^{*}}$, Lies Amin Lestari1,b, Syafi'ul Anam ${ }^{1, c}$ \\ ${ }^{1}$ Language and Literature Education Study Program, Postgraduate, State University of Surabaya, Surabaya, Indonesia \\ a angellanovitaningrum16070835021@mhs.unesa.ac.id; b lieslestari@unesa.ac.id; c syafiulanam@unesa.ac.id \\ ${ }^{*}$ Corresponding Author: \\ Whatsapp number: [085655744737]
}

How to Cite : Novitaningrum, A., Lestari, L., A., Anam, S. (2020). Teachers' Questioning Strategies to Promote Students' Critical Thinking in EFL Classroom: Perceptions And Practices. International Journal for Educational and Vocational Studies, 2 (1), 53-59. DOl: https://doi.org/10.29103/ijevs.v2i1.1977

\section{ARTICLE HISTORY}

Received:19 October 2019

Revised: 28 December 2019

Accepted: 22 January 2020

\section{KEYWORDS}

Teachers' Questioning Strategies; Critical Thinking;

Teachers' Perceptions;

Teachers' Practices

\section{ABSTRACT}

This study was intended to describe teachers' perceptions and practices of questioning strategies to promote students' critical thinking in EFL classroom. It was a descriptive qualitative research that investigated two English teachers who taught at eighth grade of Junior High School in Trenggalek. Interview and observation were conducted to collect data in order to answer research questions. The findings showed that; first, two teachers who became participants of this study had positive perceptions that practicing appropriate questioning strategies could stimulate students to think critically in learning process, and second, the teachers applied some types of questioning strategies, those were, wait-time, probing, prompting, and reinforcement. In conclusion, reffering to the issue of promoting students' critical thinking as a result of recent curriculum (K-13), teacher's questioning strategies was useful to be considered in teaching and learning process, and teachers' perceptions was one of factors that influence their' practices in classroom context.

This is an open access article under the CC-BY-SA license.

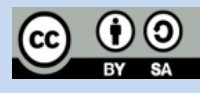

\section{INTRODUCTION}

Based on the recent curriculum (K-13), students of junior high school are required to have critical thinking. Critical thinking is a necessity skill to engange in EFL teaching and learning process because it is beneficial for students' academic achievement and future. It teaches variety of skills that can be applied in any life situations. As an illustration, when learning in primary or secondary school, students need strong critical thinking skill to process every knowledge effectively which includes analyzing and evaluating information of certain issue, taking rationale judgment and finding problem solving. It is in line with Choy \& Cheah (2009) that critical thinking is complex process which requires higher level of cognitive skill to process information. Further, many jobs require their employees to think critically in analyzing data, choosing the best decision, and acting and taking responsibility on their choices. Hence, the earlier students cultivate critical thinking, the more skilled they will be in decision making by thoughtfully analysis of the challenges they will face. Paul \& Elder (2014) point out that students who understand how to look over and critique ideas are able to make connection among diciplines, and see knowledges as useful as applicable to their daily life. Therefore, every teacher has to look for exciting ways in order to promote students' critical thinking skill in EFL classroom.

However, promoting students' critical thinking is not easy because it needs to set standard of criteria in evaluating and improving students' rational and analytical skill on facing certain issue. Teachers have to change their role not only as the source of learning, but also facilitate, motivate and stimulate students to develop their knowledges independently so that it will encourage students to think in higher level. Hence, it becomes great challenge for the most EFL teachers to modify their way of teaching. In recent years, several studies have been conducted concerning how to promote students' critical thinking. For instance, encouraging students to think critically through integrating digital storytelling (Yang \& $\mathrm{Wu}, 2012$ ), implementing active-learning strategies such as role-play, case study, and small groups (Nelson \& Crow, 2014), applying blended learning (Giraldo-Garcia, Roy \& Alotebi, 2015), utilizing instructional strategies such as - 
explicit instruction, teacher questioning, and active and cooperative learning strategies (Zhao, Pandian \& Singh, 2016), and using literary texts (Stefanova et al., 2017).

Like any other academic skills, critical thinking requires a large amount of practice so that teachers should give much efforts as creative as they can in order to find interesting and appropriate materials or strategies. One of the major goals in teaching critical thinking is enhancing students' confidence and motivation to be active learners in delivering their reasonable opinion, idea or thought to build active and meaningful interaction in classroom activities. However, most problems show that students often engange passively in classroom discussion, or they learn the material without truly thinking about and connect with what they have known. Consequently, teachers need to find solution, and questioning strategies can be stepping stone for teachers to engange their students actively communicate, and deliver their thoughts in learning process (Brown, 2001). Teachers' questioning strategies can be defined as sequence of activities which teachers use in delivering question. In teaching and learning process, question is one of the most important devices that stimulate and maintain students' interest and motivation to be actively involved in learning process, encourage them to think and focus on the lesson content, provide opportunities to share their reasonable thoughts, and seek responses from their teachers or friends (Cotton, 2000). Therefore, to practice classroom questioning, teachers must be kowledgeable on the process of framing and how to pose question (Orlich, 2010). Having actively familiar with appropriate questioning strategies can help teachers to obtain the goals of questioning. Teachers should be aware on how to use questioning strategies for different purposes.

In connection with the ideas above, what teachers do in teaching and learning in the classroom can be largely governed by their perceptions. Teachers' perceptions mean a point of view that influence their thought and thinking process to shape their own understanding of certain issue. Further, what they perceive to work best often serve to act as filters through which instructional judgments and decisions are made (Hall, 2005; Harmer, 2001). Thus, how teachers perceive on questioning strategies may become one of significant factors that influences their practices in delivering questions. In addition, teachers' practices can be look as the further issues in this study. In this case, teachers' practices mean the actual application of questioning strategies used in the EFL classroom. Furthermore, how teachers use strategies to pose question in classroom have been investigate by some reseachers. Fitriati, Isfara \& Trisanti, (2013) conduct a qualitative case study to examine English teachers skills in classroom questioning. The data are collected from audio-video recordings, transcripts of the lessons, classroom observation notes, and teachers' interviews. The transcriptions are analysed by using Wu's taxonomy of questioning strategies
(1993), and it reveals that the first teacher often uses decomposition strategy, while the second teacher tends to apply repetition strategy to deliver some questions during teaching and learning process. Another study conducted by Affandi (2015) that teacher employs some questioning strategies in teaching speaking to get students' responses of his display and referential questions. Those questioning strategies used by teacher are phrasing questions clearly, providing wait-time, providing positive feedback to students answer, and probing students' answers to improve them.

Those previous studies above are concerned with the use of teachers' questioning strategeis and their effects on students' verbal responses in classsroom interaction. There are limited studies which investigate teacher's questioning strategies to promote students' critical thinking. Differently with those previous studies, this research will be conducted in Junior High School, and can be simplified to discuss two problems below:

1. How are teachers' perceptions of questioning strategies to promote students' critical thinking in EFL classroom ?.

2. How do teachers practice questioning strategies to promote students' critical thinking in EFL classroom?.

\section{METHODS}

\subsection{Research Design}

This study used descriptive qualitative as the research design. It dealed with the study of human behavior and social life in natural setting. Further, descriptive qualitative research was applied when the study did not use statiscally analysis. It was accordance with Bogdan \& Biklen (2003) stated that the study which considered as qualitative based on some reasons, those were, adopting natural setting in classroom as source of data, using researcher as the key of instrument, and describing facts of the subjects. In addition, it uses naturalistic approach that seeks to understand phenomenon in context specific settings where researcher does not attempt to manipulate the phenomenon of interest. In this study, the researcher expects that she finds out what is really going on, captures and desribes in depht of every single phenomenon of teachers' questioning strategies under investigation related to the research objectives.

\subsection{Subjects and Setting of the Study}

In conducting this research, two English teachers who taught at eighth grade of Junior High School were involved as participants of this study. Those two teachers was chosen because they were included as experienced teachers since they had taught English more than 10 years. Moreover, this research investigated two different classes which had different students' characteristic and 
classroom atmosphere. In additon, it was expected that critical discussion would appear under investigation so that teachers' questioning strategies were highly discovered. While, the setting of this research is one of favorite schools in Trenggalek. This school was choosen since it has been accredited A, and has applied Kurikulum 2013 (K-13) from the previous years under its revision and regulation. Further, it has heterogeneous students' competence which academic and non-academic achievements are successfully gained by the students.

\subsection{Data Collection Techniques}

In order to answer two research questions stated in this study, interview and observation were conducted to collect data. Interview was used to gather data from people's point of views, opinions, beliefs, and feelings of situations in their own words. In this research, semi-structured interview was applied in order to give much greater freedom to ask in case of need, supplementary questions or even to ommit certain questions needed. The use of audio recording was intended to help interviewer gaining all of detailed data during interview.The data gotten from teachers' interview results was used to answer first research question related to the teachers' perceptions of questioning strategies to promote students' critical thinking in EFL classroom. While, observation used to find out and capture the real classroom activities when teachers practiced strategies to pose questions. In this case, the researcher became a non-participant observer who only sit in the back without getting involve in teaching and learning process. Fieldnotes were used to complete the observation technique. Therefore, audio recording was utilized to support the fieldnotes in gathering and collecting the data needed in order to get detailed activities which were not covered through direct observationIt was used to answer second research question that concern to related to the teachers' practices of questioning strategies to promote students' critical thinking in EFL classroom.

\subsection{Data Analysis Techniques}

The data gathered from observation and interview will be selected and analyzed using three stages as proposed by Miles, Huberman \& Saldana (2014), those were, data condensation, data display and conclusion drawing / verifying. To answer first research question, the data gained from interview, audio recording are transcribed and coded to investigate teachers' responses related to their perceptions of questioning strategies to promote students' critical thinking in EFL classroom. The following symbols employed by the researcher to code the data from interviews' result:
Table 1. Teachers' Interview Code

\begin{tabular}{cc}
\hline Code & Explanation \\
\hline Int-T1 & Teacher Interview 1 \\
Int-T2 & Teacher Interview 2 \\
\hline
\end{tabular}

Then, it moved to the next data analysis. Here, data from interview are displayed in the form of narrative. After completing data condensation and display, the data are analyzed descriptively to interprete the data based on related theories. In addition, to answer second reasearch question, the data gained from classroom observation were also analyzed in three stages as stated before. The researcher's notes and audio-video recording were transcribed and coded based on subject observed and times when the researcher did observation. The code used could be illustrated in the table 2 .

Table 2. Teachers' Classroom Observation Code

\begin{tabular}{cc}
\hline Code & Explanation \\
\hline CO-1 & Classroom observation \\
CO-1.T1 & Classroom Observation 1 Teacher 1 \\
CO-1.T2 & Classroom Observation 1 Teacher 2 \\
CO-2 & Classroom Observation 2 \\
\hline
\end{tabular}

Further, to conduct transcription of classroom observation, the researcher used transcribing convention as proposed by Allwright \& Bailey (1991), as seen below:

Table 3. Modified Transcription Convention and Symbols (Allwright \& Bailey, 1991)

\begin{tabular}{cc}
\hline Code & Explanation \\
\hline T & Teacher \\
S1 & Students using number (S1, S2, etc) \\
SS & Unidentified subgroup speaking in chorus \\
$T+S$ & Teacher and unidentified subgroup \\
SSS & Whole class speaking in chorus \\
$T+$ SSS & Teacher and whole class \\
[ ] & For comments \\
X & Incomprehensible item, one word \\
XX & Incomprehensible item, phrase length \\
XXX & Incomprehensible item beyond phrase length \\
II & Pauses \\
Italics & Indonesian language \\
\hline
\end{tabular}

After doing condentation, the data gotten from the classroom observation was analyzed as done in the first data; displaying and drawing conclusion. Then, it used to answer the second research question stated in this study. 


\section{RESULTS AND DISCUSSION}

The brief description of findings for each research question was presented below supporting with detailed narratives of the evidences and selection of exemplary excerpts found in the result of teachers' interview and classroom observation. Then, it followed by argumentative description about the results of this research by comparing and constrasting with the interrelated theories and relevant research findings. This session was divided into two parts; first, describing teachers' perceptions of questioning strategies to promote students' critical thinking in EFL classroom, and second, describing teachers' practices toward it. In more details, below were the elaboration of each result of this study:

\subsection{Teachers' Perceptions of Questioning Strategies to Promote Students' Critical Thinking in EFL Classroom.}

The following data was explained based on the teachers' responses of interview. When both teachers asked about their understanding of questioning strategies, they express similar statement, as illustrated below:

\section{Iya cara kita bertanya atau menggali informasi dari siswa. Mungkin itu. (Int-T1) \\ Iya mungkin bagaimana cara guru untuk bertanya kepada siswa dalam proses pembelajaran, entah itu di awal, tengah atau akhir pembelajaran. (Int-T2)}

Afterward, the researcher asked further question about whether or not those questioning strategies applied by teachers could promote students' to think critically, and two teachers had positive responses, as seen below:

\section{Sudah, tapi mungkin belum semua siswa. (Int-T1) \\ Mungkin sudah. Tapi sampai saat ini saya masih berusaha untuk mendorong siswa agar terbiasa berfikir kritis. (Int-T2)}

Concerning to the teacher's interview result above, questioning strategies could be considered by the teachers as a reference in order to achieve one of the curriculum 2013 objectives. This curriculum is the recent curriculum implemented in this school that became the seetting of this study, and required students to have critical thinking. The previous idea was accordance with Brown (2001) that delivering questions in certain ways could be stepping stone for the teachers to develop students level of thinking in learning process. In addition, Richards \& Lockhart (2007) proposed that stimulating students to provide higher level responses could be achieve by employing appropriate strategy in classroom questioning. In addition, questions became one of the most important devices in guiding and extending students' thought because the level of students' thinking was strongly influenced by teachers' questions. In other words, delivering questions gave some benefits to create effective and meningful activities in classroom context, and it had important role to promote students' critical thinking in EFL classroom.

To confirm that those questioning strategies employed by teachers had positive impact in order to promote EFL students' critical thinking, the teachers have some indicators that indicate their students think critically. Both teachers assumed when their students answered question followed by logical reasoning, it could be indicated that they had thought critically. Furthermore, $\mathrm{T} 1$ added one indicator that the students who included as critical thinker is those students who were able to fulfill all aspects related to the standard competences in terms of knowledge and skills. It was in line with Fisher (2011) that students who thought critically were able to identify problem so that they could made reasonable reasons and conclusions.

\subsection{Teachers' Practices of Questioning Strategies to Promote Students' Critical Thinking in EFL Classroom.}

This second result described teachers' practices of questioning strategies to promote students' critical thinking in EFL classroom. Here, the teachers practice some questioning strategies including wait-time, probing, prompting and reinforcement. The elaboration below could explain how teacher used those kinds of strategies in order to pose question during teaching and learning process. In addition, it followed by some selection of exemplary excerpts found in the classroom observation.

The first questioning strategies applied by teachers is wait-time strategy. It could be seen on the following excerpts:

$\begin{array}{lll}\mathrm{T} & : & \text { What is the moral value of this song? } \\ \mathrm{SSS} & : & \text { [Silent] } \\ \mathrm{T} & : & \text { What we can learn from this song? [5s] } \\ \mathrm{SSS} & : & \text { [Silent] } \\ \mathrm{T} & : & \text { Anybody knows? [3s] Hmmm... [10s] } \\ \mathrm{S} 9 & : & \text { Tetap semangat, jangan takut. }\end{array}$


The excerpt above illustrated that teacher and students had a classroom discussion about a song. In that case, teacher initiated a question about the moral value of song being discussed, as seen in line 1 . Because there were no students' responses, the teacher gave certain thinking time. First, she gave 5 seconds. However, the students were still silent. After she added wait-time 3 seconds and 5 seconds, a student gave certain response, as in line 6 . In this case, teacher used wait-time strategy type 1 . In this study, the teachers tended to give 3-10 seconds thinking time. The amount of time was effective as stated by Brown
(CO-T1.2)

(2001) that provided pause time 5-10 seconds could help students gaining ideas, then they would become a part of classroom discussion.

Another data showed that teacher also applied wait-time strategy type 1 and 2 . As already known that there were two types of teacher's wait-time strategy. First, wait-time 1 was implemented by giving a pause time between teachers asked question and students began to answer. Second, wait-time 2 was implemented by giving a pause time after students elicit response and before teacher gave feedback.

$\begin{array}{lll}\mathrm{T} & : & \text { What do you think about the song? } \\ \mathrm{SSS} & : & \text { [Silent] } \\ \mathrm{T} & : & \text { Come on. Siapa yang ingin berpendapat? What do you think } \\ & & \text { about the song? [5s] } \\ \mathrm{S} 8 & : & \text { The song is great. It can inspire me. } \\ \mathrm{T} & : & \text { It can inspire you to...? [3s] } \\ \mathrm{S} 8 & : \text { Meraih mimpi. } \\ \mathrm{T} & : \text { To reach a dream. Good. }\end{array}$

In that situation the teacher applied wait-time strategy type 1 and 2 . Wait-time strategy type 1 appeared when teacher asked students about the song. However, the students were silent. Then, one of students gave response after the teacher gave 5 seconds. In order to clarify students answer, the teacher asked further
(CO-T2.2)

question and gave 3 seconds. In this case, Here, the teacher applied wait-time strategy type 2 .

The second questioning strategies used by teachers is probing strategy, as exemplified on the teacher's and student' interaction below:

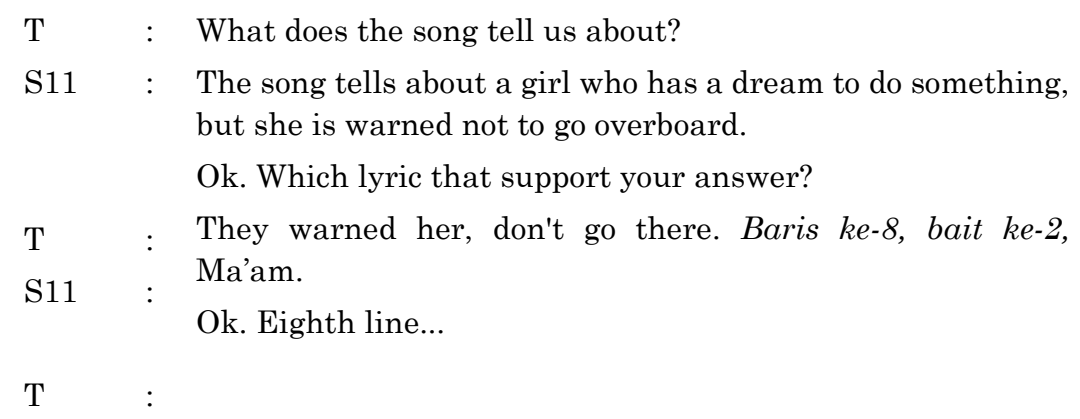

(CO-T1.2)

In the excerpt above, the teacher probe student's answer. Here, the teacher could probe initial student's response which need more explanation, reason or supporting statement. It was in line with Wu (1993) that probing was one of effective questioning strategies that

\section{encouraged students to elaborate their answers}

The third questioning strategies applied by teachers is prompting strategy. Below are the illustration of how teacher practiced this questioning strategiy in EFL classroom:

$$
\begin{array}{lll}
\mathrm{T} & : & \text {...Then, what happen next? } \\
\mathrm{SSS} & : & {[\text { Silent] }} \\
\mathrm{T} & : & \text { The song tells that the girl goes overboard eventhough she }
\end{array}
$$


warned to go? Right?

SS : Yes

T : Ok. Now please look at the song lyric carefully. Bait ke-3. After the girl goes overbroad, she follows the creatures to the top over the mountains or valley low. Have you found?

$\begin{array}{ll}\text { SSS } & : \text { Yes. } \\ \mathrm{T} & : \text { So, what happen after the girl follows the creatures? } \\ & \\ \mathrm{S} 12 \quad \text { She knew that she was hypnotized, then walking on cold } \\ \quad \text { thin ice. Bait ke-4. Yes, Ma'am? } \\ \mathrm{T} \quad \text { Iya. Very good... }\end{array}$

(CO-T1.2)

The illustration above showed that the teacher wanted students to deliver their opinions about the story happened in the song. However, there was no responses as seen in illustration above that all of the students were silent. In this case, teacher tried to give some clues so that students could answer teacher's question, as showed in line 3-10. As showed in line 3, teacher asked all of students to read the song lyrics. Finally, a student could answer teacher's question. It supported by Elliott (2005) that if students' responses were partial or superficial responses or even no responses, teacher has to facilitate prompts in order to get students' answer of teacher's questions.

The last questioning strategies applied by teachers is reinforcement strategy. It could be seen in the following exemplary excerpt:

\section{$\mathrm{T} \quad$ : Jangan takut? \\ S12 : Kan itu Ma'am... Elsa punya kekuatan sihir jadi dia pergi dari istana karena takut orang-orang akan mengejek. Seharusnya Elsa tidak perlu takut dengan omongan orang karena kan dia tidak jahat.}

Oh, I see. So, this song motivates us to make our fears as strenghts until we can be strong and accept ourselves as we

$\mathrm{T}:$ are. This song was told that Elsa is finally able to be herself.

\section{(CO-T1.2)}

The excerpt above indicated that teacher gave feedback to the student's answer. As showed that the student responded teacher's question in Indonesian. Here, teacher repeated student's answer in English. It was accordance with Richards and Lockhart (2007) that giving feedback served to let students knew how well they performed, increased their motivation, and built supportive classroom atmosphere. Besides, it could make students think in higher level.

\section{CONCLUSION}

Based on the results and discussion elaborated in the previous sections, it could be concluded that teachers who become participants of this study have positive perceptions toward questioning strategies to promote students' critical thinking in EFL classroom. Furthermore, the analysis of classroom observations revealed that the teachers used some types of questioning strategies, namely, wait-time, probing, prompting and reinforcement which effective to promote students' critical thinking in EFL classroom. Teacher's wait-time strategy was applied by giving adequate thinking time after teachers asked question and before students began to answer. Teacher's probing strategy was employed by asking students to give rational reasons and supporting evidences of their answers, and clarifying students' responses of teacher's questions. Further, teachers' prompting strategy was implemented by giving clues to elicit or complete students' answers. In addition, teachers' reinforcement strategy was applied by providing students with feedback to their performances. 


\section{REFERENCES}

Affandi, Y. (2015). Tacher's Display and Referential Questioning Teaching Speaking (Unpublished master's thesis). Universitas Negeri Surabaya.

Allwright, D., \& Bailey, K., M. (1991). Focus on the Language Classroom: An Intoduction to Classroom Research for Language Teacher. London: Cambridge University Press.

Brown, H., D. (2001). Teaching by Principle: An Interactive Approach to Language Pedagogy. New York: Addison Wesley Longman, Inc.

Bogdan, R., \& Biklen, S. (2003). Qualitative Research for Education: An Introduction to Theory and Practice. Boston: Allyn and Bacon.

Choy, S., \& Cheah, P. (2009). Teacher Perception of Citical Thinking among Students and Its Influence on Higher Education. International Journal of Teaching and Learning in Higher Education, 20(2), 198-206. DOI: https://eric.ed.gov/?id=EJ864337

Cotton, K. (2000). Classroom Questioning. Paper presented at the North West Regional Education Laboratory, Kansas.

Elliott, D., C. (2005). Teaching on Target: Models, Strategies and Methods that Work. Corwin Press.

Fisher, A. (2011). Critical Thinking: An Introduction (2nd ed.). UK: Cambridge University Press.

Fitriati, S., W., Isfara, G., A., V., \& Trisanti, N. (2017). Teachers' Questioning Strategies to Elicit Students' Verbal Responses in EFL Classes at a Secondary School. Journal of English Education, 5(2), 217-116. DOI: https://www.researchgate.net/Publication/317364 401_Teachers'_Questioning_Strategies_To_Elicit _Students'_Verbal_Responses_In_Efl_Classes_At _A_Secondary_School

Giraldo-Garcia, R., Roy, M., \& Alotebi, H. (2015). The Interplay of Technology and Critical Thinking Skills in the 21st Century Blended Classroom. International Journal of Advanced Research in Education Technology, 2(3). DOI: https://www.researchgate.net/publication/321934 531_The_Interplay_of_Technology_and_Critical_ Thinking_Skills_in_the_21st_Century_Blended_ Classroom

Hall, L., A. (2005) Teachers and Content Area Reading: Attitudes, Beliefs and Change. Teaching and Teacher Education, 21, 403-414. DOI: http://dx.doi.org/10.1016/j.tate.2005.01.009

Harmer, J. (2001). The Practice of English Language Teaching (3rd ed.). London: Longman.

Miles, M., B., Huberman, A., M., \& Saldana, J. (2014). Qualitative Data Analysis: A Methods Sourcebook (3rd ed.). USA: SAGE Publications, Inc.
Nelson, L., P., \& Crow, M., L. (2014). Do active-Learning Strategies Improve Students' Critical Thinking. Higher Education Studies, 4(2). DOI: https:/files.eric.ed.gov/fulltext/EJ1076485.pdf

Orlich, D., Harder, R., Callahan, R., Trevisan, M., \& Brown, A. (2010). Teaching Strategies: A guide to Effective Instructions (9th ed.). Boston: Wadsworth Cengage Learning.

Paul, R., \& Elder, L. (2014). The Miniature Guide to Critical Thinking Concepts and Tools. Tomales, CA: Foundation for Critical Thinking Press.

Richards, J., C., \& Lockhart, C. (2007). Reflective Teaching in Second Language Classrooms. Cambridge: Cambridge University Press.

Stefanova, S., Bobkina, J., \& Perez, F., J., S. (2017). The Effectiveness of Teaching Critical Thinking Skills through Literature in EFL Context: A Case Study in Spain. International Journal of Applied Linguistics \& English Literature, 6(6). DOI: https://www.researchgate.net/publication/319422 865_The_Effectiveness_of_Teaching_Critical_Thi nking_Skills_through_Literature_in_EFL_Conte xt_A_Case_Study_in_Spain

Wu, K., Y. (1993). Classroom Interaction and Teacher Questions Revisited. RELC Journal, 24(1), 49-68. DOI: https://doi.org/10.1177/003368829302400203

Yang, Y., C., \& Wu, W., I. (2012). Digital Storytelling for Enhancing Student Academic Achievement, Critical Thinking, and Learning Motivation: A Year-Long Experimental Study. Computers \& Education: An International Journal, 59, 339-352. DOI:

https:/www.sciencedirect.com/science/article/abs/ pii/S0360131511003289

Zhao, C., Pandian, A., \& Singh, M., K., M. (2016). Instructional Strategies for Developing Critical Thinking in EFL Classrooms. English Language Teaching, 9(10). DOI: https://eric.ed.gov/?id=EJ1111989 